"This is an Accepted Manuscript of an article published by Taylor \& Francis in Journal of Medieval History on 07/09/2015, available online:

http://www.tandfonline.com/10.1080/03044181.2015.1083880."

\title{
The Kingdom of Portugal, Homage, and Papal 'fiefdom' in the second half of the twelfth Century
}

Benedict G. E. Wiedemann*

Department of History, University College London, Gower Street, London, WC1E 6BT

(Received 8 April 2014; final version received 28 August 2014)

This paper examines the relationship between the newly-formed kingdom of Portugal and the papacy in the second half of the twelfth century. The kings of Portugal sought a close alliance with the papacy and their relationship has been seen as that of 'vassal' and overlord. However, it seems likely that this alliance owed more to the tradition of monastic protection grants. The act of homage performed to the papal legate by King Afonso I is an example of a wider use of the homage ceremony. Homage was not only used to cement 'feudal' bonds, but also to make peace or to confirm pacts and agreements. The annual census paid by the kingdom to Rome was part of the same grant of protectio. The papal-Portuguese letters used the same language and terminology as ecclesiastical protectio, which was awarded by the papacy to monasteries, churches and eventually kingdoms and kings.

Keywords: Portugal; papacy; homage; overlordship; protectio 
In December 1143 Afonso Henriques, self-declared King of Portugal, confirmed in a letter to Pope Innocent II that he had performed homage - hominium facere - to the papacy through the papal legate, Cardinal Guido, and offered his land to St Peter under an annual census or render of four ounces of gold. ${ }^{1}$ Innocent had died several months previously, as had his successor, Celestine II, and it was the next pope, Lucius II, who dispatched a confirmation of the letter in May 1144. ${ }^{2}$ However the papacy did not recognize Afonso as king until 1179, instead addressing him merely as dux Portugalensis - duke of Portugal. Shortly before Afonso had allied himself with the papacy, he had also confirmed the Treaty of Zamora with Alfonso VII of Castile-León, by which the Castilian emperor had recognised the royal status of the Portuguese ruler. Afonso's alliance with the papacy has therefore been recognised quite rightly as a further attempt to emphasise his new kingship and his independence from Castile-León. There has been a tendency to paint the papal-Portuguese alliance in feudal terms by describing Portugal as a papal fief and Afonso as a papal vassal. ${ }^{3}$ It is Afonso's homage to Cardinal Guido and its aftermath which have been used to justify the use of such terms as 'fief' and 'vassal'. Johannes Fried, however, suggested that the relationship more resembled one of protection than overlordship. ${ }^{4}$ In this he was followed by Ian Robinson. ${ }^{5}$ Most recently José Mattoso perceptively commented that, other than the census, Afonso owed no other services to Rome and agreed with Fried about the character of the

\footnotetext{
*E-mail: benedict.wiedemann.09@ucl.ac.uk

${ }^{1}$ The following abbreviation is used in this paper: PL: Patrologiae cursus completus, series Latina. Claves regni, in Variorum ad Lucium papam 18 epistolae, ed. J.-P. Migne. PL 179 (Paris: Garnier Fratres, 1899), 935-6: 'Ego Adefonsus ... domino et patri meo papae Innocentio hominium feci, et terram ... meam beato Petro ... offero.' For variations in the surviving versions of Claves regni, see A. Patricía Dias and M. Fernandes, 'Em torno da Claves regni - Do texto à simbólica do miles Sancti Petri', in Actas do Colóquio poder espiritual/poder temporal: as relações estado-igreja no tempo da monarquia (1179-1909) (Lisbon: Academia Portuguesa da História, 2009), 350-82.

${ }^{2}$ Devotionem tuam, in Lucii II pape epistolae et privilegia, ed. J.-P. Migne. PL 179: 860-1.

${ }^{3}$ C. Erdmann, Das Papsttum und Portugal im ersten Jahrhundert der Portugiesischen Geschichte. Abhandlungen der Preussischen Akademie der Wissenschaften, Phil.-Hist. Klasse N. 5 (Berlin: Preussischen Akademie de Wissenschaften, 1928), 29-32.

${ }^{4}$ J. Fried, Der päpstlicher Schutz für Laienfürsten: die politische Geschichte des päpstlichen Schutzprivilegs für Laien (11.-13. Jahrhundert) (Heidelberg: Winter, 1980), 140-2. While Fried did identify Portugal as being under papal protection rather than overlordship, he did not analyse the relationship in the same detail as Aragon. ${ }^{5}$ I. Robinson, The Papacy 1073-1198 (Cambridge: Cambridge University Press, 1990), 304.
} 
relationship. ${ }^{6}$ But even Mattoso referred to the 'vassalage' of Afonso, ${ }^{7}$ despite the fact that he clearly also recognised that such a term - using the language of feudo-vassalic relations - did not properly describe the character of the relationship. Despite the homage ceremony it seems unlikely that the relationship was 'feudo-vassalic', and this paper therefore re-examines the detail of the connection between Portugal and the papacy.

The homage in the papal-Portuguese alliance may not be all it seems. The act of homage appears to only have been performed in 1143 and was hardly considered by either the papacy or the Portuguese kingdom thereafter. When one looks at the letters between the papacy and Portugal which dealt explicitly with the terms of the relationship and its aftermath, all mention of homage or overlordship was absent. The majority of these letters survive only after the grant of the title of 'king' in 1179 .

Manifestis probatum is, without doubt, the best-known letter from the Holy See to Portugal from the twelfth century. ${ }^{8}$ This was the 1179 missive of Alexander III which granted Afonso and his successors the title of 'king' - rex - although Afonso had been using it for himself anyway for some decades. ${ }^{9}$ This title was granted in return for an annual census of two marks of gold. At no point in the letter was any mention made of homage, past, present or future. Nor was there reference to any particular rights or dues other than the annual census.

The papacy's grant of the title of rex in 1179 has generally been ascribed to Afonso's willingness to increase the census, probably at the same time he dictated his new will in February $1179 .{ }^{10}$ This new will, while not mentioning the papacy specifically, divided up the

\footnotetext{
${ }^{6}$ J. Mattoso, D. Afonso Henriques (Lisbon: Centro de Estudos dos Povos e Culturas de Expressão Portuguesa, 2007), 214.

${ }^{7}$ Mattoso, D. Afonso Henriques, 214, 215.

${ }^{8}$ Manifestis Probatum, in Alexandri III Romani pontificis Opera omnia, ed. J.-P. Migne. PL 200 (Paris: J.-P. Migne, 1855), 1237-8; the original 1179 bull has been digitised by the Portuguese National Archive and is available online at http://digitarq.arquivos.pt/viewer?id=3908043 (accessed: 10/08/2015).

9 'Regnum Portugalense cum integritate honoris regni et dignitate quae ad reges pertinent ... excellentiae tuae concedimus.'

${ }^{10}$ Mattoso, D. Afonso Henriques, 359-60.
} 
22,000 maravedís $^{11}$ which were kept for Afonso at his monastery of Santa Cruz, as well as his other funds. A huge amount was given to ecclesiastical institutions, such as the Hospital in Jerusalem. ${ }^{12}$ At the same time, the argument goes, Afonso expressed a willingness to pay a heavier census to the pope and offered a one-off gift of 1,000 aurei. The negotiations for the grant of the title of rex were then carried out directly with the pope, either by the archbishop of Braga during the Third Lateran Council (5-19 March 1179) or by Master Juliao Pais. ${ }^{13}$ Interestingly the papal chancery first styled Afonso rex before the issue of Manifestis probatum on 23 May $1179 .{ }^{14}$ On 13 April 1179, Alexander III issued a privilege for the Templars which described Afonso's mother, Teresa, as 'the mother of our most beloved son in Christ, the illustrious king of Portugal'. ${ }^{15}$ This fits in well with the argument that the negotiations to grant the title to Afonso took place before April 1179, possibly at Lateran III in March; by April 1179 - immediately after the Lateran council - the papacy was clearly prepared to allow Afonso the title of king, although the particular form of words used would probably have been suggested by the petitioner rather than the papal chancery. Damien Smith has also pointed to two other references to Afonso as rex, both from 1173 and both made by the then papal legate, Cardinal Jacintus (later Pope Celestine III, 1191-8). ${ }^{16}$ These two references might suggest that the papacy was considering elevating Afonso six years before Manifestis probatum. However, it is also the case that the papal chancery continued to style

\footnotetext{
${ }^{11}$ An Iberian gold coin. Although they were not of exactly equal value, the papal chamber appears to have treated the maravedi as equivalent to both the byzantius and aureus, other common gold coins, both of which are referred to below. V. Pfaff, 'Die Einnahmen der römischen Kurie am Ende des 12. Jahrhunderts', Viertaljahrschrift für Sozial- und Wirtschaftsgeschichte 40 (1953): 98, 108-9.

${ }^{12}$ Rui Pinto de Azevedo, ed., Documentos medievais Portugueses: documentos régios, vol. 1 (Lisbon: Academia Portuguesa da História, 1958), 436.

${ }_{13}$ Mattoso, D. Afonso Henriques, 359-60.

${ }^{14}$ D. Smith, 'Alexander III and Spain', in Pope Alexander III (1159-81): the Art of Survival, eds. P. Clarke and A. Duggan (Farnham: Ashgate, 2012), 221.

15 'Mater carissimi in Christo filii nostri illustris Portugalensium regis': C. Erdmann, Papsturkunden in Portugal. Abhandlungen der Gesellschaft der Wissenschaften zu Göttingen. Phil.-Hist. Kl. Neue Folge 20 (Berlin: Gesellschaft der Wissenschaften zu Göttingen, 1927), 248.

${ }^{16}$ Smith, 'Alexander III and Spain', 221.
} 
Afonso dux rather than rex in a letter of $1177 .{ }^{17}$ It seems likely, therefore, that Jacintus' use of rex was either an oversight or an example of diplomatic discretion. It did not at this stage signify papal acceptance of Afonso's requests for the royal title.

The language used in Manifestis probatum was mild, the newly-made king was taken under 'blessed Peter's and our own protection', ${ }^{18}$ and the census was said to show the right of St Peter in that kingdom. ${ }^{19}$ A useful comparison can be made between this grant to Afonso and the 1139 grant by Innocent II of a royal title to Roger of Sicily - Quos dispensatio. ${ }^{20}$ There were numerous similarities between the two letters. The long justificatory section beginning Manifestis probatum est was almost identical on both, although one has to make allowance for the fact that the one who had 'intrepidly extirpated the enemies of the Church' in the Sicilian letter was Roger de Hauteville, King Roger's father, rather than Roger himself. The majority of Manifestis probatum can be found in extremely similar phrasing in Quos dispensatio and the language used to describe the grant of the royal dignity was similar, although admittedly the Sicilian letter felt the need to make reference to a mythical, ancient tradition of a Sicilian kingdom. The main difference between the two was that it was noted that Roger of Sicily's successors must make 'liege homage and swear fidelity, as he has sworn'. ${ }^{21}$ The Portuguese letter made no reference to any hominium or homagium required, nor to any previously done. Norman dukes had been performing homage since $1120,{ }^{22}$ and

\footnotetext{
${ }^{17}$ Erdmann, Papsturkunden in Portugal, 245, cited in Smith, 'Alexander III and Spain', 221.

18 'Sub beati Petri et nostra protectione'.

19 'Ad indicium ...quod praescriptum regnum beati Petri iuris existat'.

${ }^{20}$ J.-P. Migne, ed., Innocentii II pontificis Romani epistolae et privilegia. PL 179: 478-9. H. Hoffman, 'Langobarden, Normannen, Päpste. Zum Legitimationsproblem in Unteritalien', Quellen und Forschungen aus Italienischen Archiven und Bibliotheken 58 (1978): 176-8. Translation in G. Loud, ed. and trans., Roger II and the Creation of the Kingdom of Sicily (Manchester: Manchester University Press, 2012), 310-12. This bull does not begin Manifestis probatum est as Luís Ribeiro Soares mistakenly thought. L. Ribeiro Soares, 'A Bula "Manifestis Probatum" e a Legitimidade Portuguesa' in $8{ }^{\circ}$ Centenário do Reconhecimento de Portugal pela Santa Sé. (Bula 'Manifestis Probatum'- 23 de Maio de 1179) (Lisbon: Academia Portuguesa de História, 1979), 148, 187-9.

21 'Et ut ad amorem atque obsequium b. Petri ... et nostrum, ac successorum nostrorum ... accingaris, haec ipsa, id est regnum Siciliae, ducatum Apuliae, et principatum Capuae, haeredibus tuis, qui nobis et successoribus nostris ... ligium homagium fecerint, et fidelitatem quam tu iurasti iuraverint ... duximus concedenda.' 22 J.-P. Migne, ed., Paschalis II, Gelasii II, Calixti II Romanorum pontificum epistolae et privilegia. PL 163 (Paris: Garnier Gratres, 1893), 1190-1, 1198-9. V. D’Alessandro, Storiografia e politica nell'Italia normanna,
} 
the obligation to perform the ceremony had been restated when the crown was granted in 1139. The details of the homage performed by the Normans were specified in neither the 1139 grant of the title of king nor in the 1156 treaty of Benevento. ${ }^{23}$ Falco, in the Chronicle of Benevento, explained that, in 1139, 'He [Innocent II] gave the kingdom of Sicily to King Roger by means of a banner', and that Roger's sons were separately invested with the duchy of Apulia and the principality of Capua. ${ }^{24}$ However the 1139 papal grant made no mention of a banner forming part of the investiture, nor of the constituent parts of the Norman territory being separately granted; indeed, Innocent's grant specifically stated that the duchy and principality were both given to Roger II himself. ${ }^{25}$ Nor did Falco specifically state that Roger performed 'homage' in 1139, as the papal privilege stated he should. Falco only referred to the swearing of 'fidelity' ${ }^{26}$ It is possible that a banner formed part of the ceremonies of homage and investiture for the Normans, but there is no indication of anything similar for Portugal. The two cases in fact appear to be quite different with only the ceremony of homage linking them. However, while the requirement of homage was re-stated in the 1139 letter and the 1156 treaty of Benevento for the Normans, it was not mentioned after 1144 for the Portuguese. If Portugal were linked to the Holy See by a bond of homage, why was the need to perform it not restated in 1179 ?

Claves regni made no requirement that the homage ceremony should ever be repeated nor did it mention the swearing of any oath. The grant of the crown to Afonso in 1179 made

(Naples: Liguori, 1978), 170-3, G. Loud, 'Norman Sicily in the Twelfth Century', in The New Cambridge Medieval History, vol. 4, c.1024-c.1198, part II, ed. D. Luscombe and J. Riley-Smith (Cambridge: Cambridge University Press, 2004), 445.

${ }^{23}$ Latin text in L. Weiland, Monumenta Germaniae historica, Constitutiones et acta publica imperatorum et regum, vol. 1 (Hanover: Hahn, 1893) 588-90. English translation in G. Loud and T. Wiedemann, eds. and trans., The History of the Tyrants of Sicily by 'Hugo Falcandus' 1154-69 (Manchester: Manchester University Press: Manchester, 1998), 248-52.

24 'Regi ... Rogerio ... Siciliae regnum per vexillum [Innocentius] donavit, duci, filio suo, ducatum Apuliae, principi, altero filio eius, principatum Capuanum largitus est': Falcone di Benevento, Chronicon Beneventanum, ed. E. D’Angelo (Florence: SISMEL - Edizioni de Galluzzo, 1998), 222.

${ }^{25}$ Migne, ed., Innocentii II ... epistolae et privilegia. PL 179: 478-9. Hoffman, 'Langobarden, Normannen, Päpste', pp. 176-8, 'Ducatum ... Apuliae ... et insuper principatum Capuanum ... tibique concedimus.'

26 'Firmaverunt [Rogerius et filii eius] beato Petro, et Innocentio papae ... fidelitatem deferre', Falcone di Benevento, Chronicon, ed. D’Angelo, 222. 
no reference either to homage or an oath. The difference between the situation of Portugal and Sicily is marked, and only made clearer by the general similarities of the letters granting the royal title in 1179 and 1139 respectively.

Strict payment of the annual census by Portugal does not seem to have been enforced for much of the rest of the twelfth century and letters - with the exception of re-issues of Manifestis probatum - did not make reference to any particular relationship between the papacy and Portugal. ${ }^{27}$ These re-issues, however, were merely re-statements of the original letter and repeated the phrasing of Alexander III. With the accession of Innocent III in 1198, Portugal began to figure more prominently in papal correspondence. Innocent, in the first year of his pontificate, dispatched letters to King Sancho I of Portugal, Afonso's son, requesting the unpaid census. Innocent stated that 'after the acceptance of the royal title, neither he [Afonso I] paid [the census] nor, afterwards, did you [Sancho I] arrange to pay'which tells us that the census had not been paid regularly since $1179 .{ }^{28}$ Most interesting is that, in the first of these letters, Innocent pointed out that the kingdom owed two censuses: the first of four ounces of gold, an obligation dating from the period of Pope Lucius; the second of 100 bizantii for the title of king, dating from the time of Pope Alexander. ${ }^{29}$ Although the currency is different, the latter was explicitly stated to have been granted in return for the royal title and to have not been paid once that title was accepted. ${ }^{30}$ It must therefore have referred to the census of 1179 . The former, however, seems to have been

\footnotetext{
${ }^{27}$ Re-issued to Sancho I by Clement III in May 1190: Erdmann, ed., Papsturkunden in Portugal, 342-3.

${ }^{28}$ J.-P. Migne, Innocentii III Romani pontificis Opera omnia, vol. 1. PL 214 (Paris: Garnier Fratres, 1890), 878: 'quos [centum bizantios] post susceptionem regii nominis nec ipse [Afonso] solvit nec tu postmodum solvere curavisti'; PL 214: 424-5; A. J. da Costa, M. A. F. Marques, eds., Bulário Português: Inocêncio III (11981216), (Coimbra: Instituto Nacional de Investigação Científica, 1989), 6.

${ }^{29}$ Migne, Innocentii III Romani pontificis Opera omnia, vol. 1. PL 214: 87-8: 'Alphonsus pater tuus quatuor auri uncias annuatim Romanae Ecclesiae constituit censuales ... Pater tuus ... centum bizantios annuatim Romanae Ecclesiae constituit censuales.'

30 '[Afonso] meruit obtinere ... regio nomine vocarentur ... post susceptionem regii nominis nec ipse [Afonso] solvit [censum].'
} 
forgotten until Innocent's accession, ${ }^{31}$ and, from both the amount and the reference to Lucius II, referred to the $1143-4$ census.

Innocent's first letter also raised the questions of how much the kingdom owed in its annual census. Originally the amount had been four ounces of gold, but this had been increased to two marks of gold - a fourfold increase - in $1179 .{ }^{32}$ The lack of any reference in Manifestis probatum to paying the earlier census suggests that the new amount was meant to supersede the previous one; that is to say, only the amount stipulated in 1179 was now expected. Innocent, however, made reference to both separately and suggested that they were separate censuses which must both be paid. It seems likely that the request for both was an innovation of Innocent and that Alexander had not foreseen that Portugal would need to pay both in 1179. But, as Innocent's letter said, it was perhaps because the 1143 census had been forgotten that it had not been paid rather than because it was now defunct.

An absence of institutional recollection could serve as one possible explanation for the absence of any repetition of homage between 1143 and Innocent's discovery of the 1143 grant in 1198. However, that argument is not convincing. Simply put, a suggestion that the homage was not renewed during those 55 years because it was forgotten reverses cause and effect. It was the fact that the homage was never intended to be repeated which meant that the letters of 1143-4 were not examined by the Curia until the accession of Innocent III; they never needed to re-examine them. Furthermore if the homage had been intended to be repeated and it was simply forgotten, then why did Innocent follow his predecessors in never

\footnotetext{
31 'In regestis ... Lucii II ... reperisse quod ... Alphonsus ... quatuor auri uncias ... constituit.'

${ }^{32}$ A mark, in terms of weight, is eight ounces. The two marks would therefore be 16 ounces. If the 100 bizantii are equivalent to the two marks then they too would have to weigh 16 ounces. The Byzantine solidus was reformed in 1092 by Alexius Comnenus, but throughout Byzantine rule it was always supposed to be equivalent to $1 / 72$ of a Roman pound (which contained 12 ounces). If 100 bizantii are equal to 16 ounces (and hence two marks) then ${ }^{100 / 72}=16 / 12$ ) and hence $72 / 100 \times 16 / 12=1$, since there were 12 ounces in a Roman pound and 72 bizantii in a Roman pound also. ${ }^{72} / 100 \times 16 / 12$ actually yields 0.96 , which is close enough to 1 to suggest that the two amounts were intended to be the same. The slight difference is probably due to variation in the weight of an ounce or in the number of ounces in a pound. For details of Byzantine currency, see P. Grierson, Byzantine Coinage (Washington: Dumbarton Oaks Research Library and Collection, 1999), 2-3 and passim; for weights and measures of pounds, ounces and marks, see R. Zupko, Italian Weights and Measures from the Middle Ages to the Nineteenth Century, (Philadelphia: American Philosophical Society, 1981), 129, 139, 174.
} 
mentioning it? The 1198 request for payment of the censuses made no reference to any homage, although Innocent must have been aware of it if he had read Lucius' 1144 letter, as we know he had. Homage was conspicuous by its absence from the first of Innocent's letters of December 1198, which merely affirmed that Portugal and King Sancho were under the protection of blessed Peter and the papacy. ${ }^{33}$ It was also noted in that letter that Sancho and his predecessors were 'always faithful to the papacy'. ${ }^{34}$ This is an important distinction: this section cannot be translated as 'making fealty' or any other anachronistic phrase denoting subjection, but simply referred merely to a tradition of having a positive relationship with the Holy See and being orthodox in Christian practices. Innocent's second letter of December 1198 was again about the census payments, but, also again, there was no reference to homage: Portugal was merely noted as being under the protection of the Apostolic See. ${ }^{35}$ The use of protectio without reference to homage occurred several times in Innocent's letters, in 1198, as discussed above, and $1211 .{ }^{36}$ In a 1211 missive dealing with ecclesiastical censures and Sancho's will Portugal was, again, said to under St Peter's protection and the kings of Portugal were referred to as 'special sons of Peter'. ${ }^{37}$ In 1212 Innocent re-issued Manifestis probatum and kept the 1179 wording essentially the same. There was no homage and the kingdom was once again stated to be under papal protection. ${ }^{38}$ There can be no doubt that, for whatever reason, homage was never mentioned nor expected after the original performance of the ritual in 1143 .

\footnotetext{
${ }^{33}$ Migne, ed., Innocentii III ... Opera omnia, vol. 1. PL 214: 419; da Costa, Marques, eds., Bulário Português, 42, 'Personam tuam et regnum Portugalensem ... sub beati Petri et nostra protectione suscipimus.' 34 'Tu et praedecessores tui ei [Romanae Ecclesiae] semper fideles exstiteritis.'

${ }^{35}$ Migne, ed., Innocentii III ... Opera omnia, vol. 1. PL 214: 424-5, 'Per apostolicae sedis protectionem'.

${ }^{36}$ The use of protectio but no mention of homage can be found in Innocent's letters of 1198 and 1211, Migne, ed., Innocentii III ... Opera omnia, vol. 1. PL 214: 419, 424-5; J.-P. Migne, ed., Innocentii III Romani pontificis Opera omnia, vol. 3. PL 216 (Paris: Garnier Fratres, 1891), 424, and also in the 1212 re-issue of Manifestis probatum, 562-3; da Costa, Marques, eds., Bulário Português, 325-7.

${ }^{37}$ P. Migne, ed., Innocentii III ... Opera omnia, vol. 3. PL 216: 423-4, 'Ipsum [Afonso] ac successores suos adoptans in beati Petri filios speciales, eos et regnum Portugalense suaque protectione curaverit communire.' See also, P. Linehan, ed., Portugalia pontificia: Materials for the History of Portugal and the Papacy, 11981417, vol. 1 (Lisbon: Fundação Calouste Gulbenkian, 2013), 129-130 (no. 68).

${ }^{38}$ Migne, ed., Innocentii III ... Opera omnia, vol. 3. PL 216: 562-3. See also, Linehan, ed., Portugalia Pontificia, vol. 1, 133 (n. 75).
} 
Afonso himself made no mention in his will of papal approval or any rights the papacy may have had in determining the succession. Indeed Rome was not mentioned at all. ${ }^{39}$ Nor did Afonso refer to either the homage or any papal overlordship in his two letters requesting papal protection for the monastery of Santa Cruz in $1156-7$ and $1162-3 .^{40}$ What then is the reason of the complete absence of the bond of homage from papal-Portuguese relations after 1144 and what does it suggest about the nature of the papal-Portuguese relationship?

In order to understand how homage fitted into Afonso's actions in 1143 it is necessary to recognise that the ceremony of homage was not solely used in the context of land grants or the ritual of becoming the homo of a lord. Paul Hyams has pointed to the role of homage as establishing a bond between persons minus all of the accoutrements traditionally associated with homage as a ritual of feudo-vassalic subjection. ${ }^{41}$ Examples from England and France illustrate that the hand-giving ceremony of homage cannot be interpreted solely in its feudovassalic setting. It was a ritual of submission, dependence or pacification which had a wide range of uses. In a case from England in the third quarter of the twelfth century, homage was performed by a knight, the brother of a murderer, to a clerk, the brother of the victim. ${ }^{42}$ This was not a 'feudal' use of homage, the knight did not become the 'man' of the clerk, there was certainly not any land changing hands, as one might find in the fully developed law codes dealing with homage, vassalage and fiefdom. The utility of this performance of homage lay in

\footnotetext{
${ }^{39}$ Pinto de Azevedo, ed., Documentos medievais Portugueses: documentos régios, vol. 1, pp. 430-1.

${ }^{40}$ Pinto de Azevedo, ed., Documentos medievais Portugueses: documentos régios, vol. 1, 317-18, 359-60. Afonso's claim of adding lands to the 'apostolic patrimony' in the second of these letters clearly referred to returning his conquered lands to the Christian (and Roman) faith after having 'taken [them] from the Saracens'. Otherwise in these letters Afonso referred to himself as miles beati Petri, filium specialem, and militem vestrum et devotum filium.

${ }^{41}$ P. Hyams, 'Homage and Feudalism: a Judicious Separation', in Die Gegenwart des Feudalismus, ed. N. Fryde (Göttingen: Vandenhoeck \& Ruprecht, 2002), 13-49. I am grateful to Phillip Fernandes for sending me an early draft of his paper, 'The Implications of Inceptus: Homage, Law, and Lordship in Medieval Wales' given at the the Seventh Bangor Colloquium on Medieval Wales, (7-9 November, 2014), which drew my attention to recent studies on the uses of homage.

${ }^{42}$ Hyams, 'Homage and Feudalism', 31-2.
} 
its efficacity as a mechanism for making peace; the bond between the men was not based on lordship, but on something else entirely.

However, the world of rural knights and clerics in twelfth-century England was a long way from that of Iberian kings and Roman popes, even in the same period. To discover whether the homage of Afonso in 1143 was 'feudal' homage or not, we must examine what that ceremony meant for the participants. The ceremony of homage might have a range of meanings in Iberia too: Hilda Grassotti has pointed to several cases which are of interest for a re-interpretation of the 1143 ceremony. ${ }^{43}$ It is noticed that hominium occurred in texts of treaties and alliances between the Spanish kings and one of these treaties, the league of Huesca, is of particular interest for us.

The league of Huesca was an alliance contracted in 1191 between three kings: Alfonso II of Aragon, Sancho of Portugal and Alfonso IX of León. Its purpose was mutual defence against a fourth king: Alfonso VIII of Castile. The Castilian king was the dominant force on the Iberian Peninsula and doubtless his increasing power had led to the three other kings attempting to prevent his rise by allying. The text of the treaty survives only in the copy made for Alfonso of Aragon, ${ }^{44}$ but we can assume that the other two kings had their own copies too, doubtless with the minor variations common to the different areas of Spain. ${ }^{45}$ The alliance was one of mutual defence: Aragon agreed not to make a treaty with Castile except with the approval of Portugal and León, and it was agreed that while either Portugal or León were at war with Castile so too was Aragon. The Portuguese and Leonese copies probably carried the same text save variations that made the text appropriate for each, with Portugal or

\footnotetext{
${ }^{43}$ H. Grassotti, Las instituciones feudo-vassalláticas en León y Castilla. 2 vols. (Spoleto: Centro italiano di studi sull'alto medioevo, 1969), 1: 174-6, 187; E. Pascua, 'Peace Among Equals: War and Treaties in TwelfthCentury Europe', in War and Peace in Ancient and Medieval History, eds. J. France and P. de Souza (Cambridge: Cambridge University Press, 2008), 201. Fried, Der päpstlicher Schutz für Laienfürsten, 142, also suggests that hominium can have connotations other than feudo-vassalic.

${ }^{44}$ J. Gonzalez, Alfonso IX: Colección diplomática. 2 vols. (Madrid: Instituto Jerómino Zurita, 1944), 2: 70-1.

${ }^{45}$ For example the Aragonese copy has already ceased to use the Spanish Era for dating while neither Portugal nor León would switch to dating using anno domini for some time.
} 
León agreeing not to make a treaty without the consent of the others and so on mutatis mutandis.

Once the terms had been stated, however, the corroboration of Alfonso of Aragon followed. 'To confirm these pacts and conventions, and that the aforesaid be observed, I, King Alfonso, make homage and provide fidelity to you, Guiraldo de Bezon, knight of the aforementioned kings [Portugal and León]. ${ }^{46}$ Alfonso also described 'placing my hands between yours [Guiraldo's]' making it clear this definitely was the homage ceremony which we see elsewhere. There can be little doubt that the homage here was done for the confirmation of an agreement. There were no changes in land ownership mentioned in the treaty or known to us; indeed, the entire tenor of the treaty was one of mutual assistance and equality between the kings. No indication was given that Aragon had any sort of inferior status and it was not stated that the kingdom of Aragon should become in any way a dependency of the other two kings. As the text quoted above makes clear, Alfonso of Aragon submitted to Guiraldo not as his 'man', but only in the sense of publically confirming he would abide by the treaty. Furthermore not only did Alfonso do homage, but a number of his most powerful magnates did too: 13 others were listed as having done homage to observe the pact. Considering the general suggestion of equality in the treaty, and the fact that we only have the Aragonese text, it seems very likely that the other two kings also did homage, along with their magnates, to confirm that they would abide by the treaty. All this makes evident the function of homage as confirmation of an agreement. The three kings did homage to show that they would abide by the terms agreed between them and there can be no implication of overlordship or vassalage in this situation. This form of homage was one used to show that the performer will abide by an agreement.

\footnotetext{
46 'Ad ... confirmacionem huius pacti et convencionis, et ut ... observentur predicta, ego, predictus Ildefonsus rex, facio et presto hominium et fidelitatem tibi Guiraldo de Bezon, militi supradictorum regum, positis manibus meis inter tuas.'
} 
Thus we would seem to have an explanation for the one-off homage received by Cardinal Guido in 1143. Afonso performed homage not as a liegeman of the Holy See but to confirm the text of the agreement between himself and the papacy, and perhaps also to confirm the other articles of the Treaty of Zamora. No homage was ever asked for or expected again because homage had never been part of the agreement between Rome and Portugal; it was used only in the Iberian custom to show they would abide by a pact. ${ }^{47}$ In the text of Claves regni, Afonso stated that he performed homage and then that he offered his kingdom to St Peter under an annual census. ${ }^{48}$ There is no indication that the homage was supposed to be repeated nor that it was an integral part of the 'offer' of land.

Other than the homage, the papal and royal letters need to be scrutinised for any suggestion of 'overlordship'. The language of the letters examined above does not lead to any such conclusion. The most common phraseology in the letters as a whole was that the kingdom and the person of the king were under the protection of St Peter and of the Holy See: this is found in the letters of 1179,1198 and $1211-2 .{ }^{49}$ In Claves regni, Afonso stated he wished for the patronage and advocacy of St Peter; ${ }^{50}$ and in Devotionem tuam it was recognised that the king's person and kingdom were under the patronage of St Peter. ${ }^{51}$ It was the notion of protection-patronage which was the recurring feature of the papal-Portuguese relationship, rather than overlordship, and it was this relationship, along with the mention of homage, which resulted in the erroneous belief that Portugal was a papal 'fief', which has been corrected by Fried and others.

\footnotetext{
${ }^{47}$ It may well be the case that the homages of the Southern Italian Normans to the papacy also fulfilled the role of being a public symbol of a new agreement, rather than being an entry into vassalage.

${ }^{48}$ Migne, ed., Variorum ad Lucium papam 18 epistolae. PL 179: 935-6.

${ }^{49}$ Migne, ed., Alexandri III Romani pontificis Opera omnia. PL 200: 1237-8 (1179); Migne, ed., Innocentii III ... Opera omnia, vol. 1. PL 214: 419, 424-5 (1198); Migne, ed., Innocentii III ... Opera omnia, vol. 3. PL 216: 423-4 (1211), 562-3 (1212).

${ }^{50}$ J.-P. Migne, ed., Lucii II papae epistolae et privilegia. PL 179 (Paris: Garnier Fratres, 1899), 935-6, 'ipsum patronum et advocatum apud Deum omnipotentem'.

${ }^{51}$ Migne, ed., Lucii II papae epistolae et privilegia. PL 179: 860-1, 'personam tuam et terram ipsam ipsius patrocinio ... commisisti.'
} 
Other than protectio there were a few other references to the status of the relationship. Afonso called himself a miles beati Petri ('knight of St Peter') in 1143, ${ }^{52}$ and Sancho and other kings were stated to be beati Petri filios speciales ('the special sons of St Peter') in 1211. ${ }^{53}$ These references do not suggest anything other than the friendship which existed between Portugal and Rome. In the same manner the observation, noted above, that the kings of Portugal have always been faithful to the Holy See, ${ }^{54}$ emphasised the close relationship between the two.

Neither the reminder that the Portuguese have traditionally been faithful to Rome, however, nor the claim that they are 'sons' of St Peter suggest a bond of subjugation; that Portugal was a fief of the Apostolic See. One could conceivably construct an argument that miles might imply a vassalic relationship. However, 'knight of St Peter' occurred too rarely to justify an inference about vassalic subordination. It is also notable that the term was used by Afonso himself and not by the papacy in its correspondence with Portugal. Afonso's 1143 use of the term occurred before the grant of the crown and it seems plausible that he used such language to emphasise his closeness to the Holy See at a time when his rule was not yet secure.

The papacy referred, in 1179, to its 'right' within the kingdom, noting that it was shown to exist by the payment of the census. ${ }^{55}$ However, the census payment was actually the only 'right' that the papacy had and payment does not appear to have been frequent, judging by Innocent III's complaints in his letter of 1198. The only definite elements of the relationship we can establish are: a commitment to pay an annual census, and the conception that Portugal was under the patronal protection of the Holy See. These commitments were

\footnotetext{
52 Migne, ed., Lucii II papae epistolae et privilegia. PL 179: 935-6; Pinto de Azevedo, ed., Documentos medievais Portugueses: documentos régios, vol. 1, 317-18.

${ }^{53}$ Migne, ed., Innocentii III ... Opera omnia, vol. 3. PL 216: 423-4.

${ }^{54}$ Migne, ed., Innocentii III ... Opera omnia, vol. 1. PL 214: 419.

${ }^{55}$ Migne, ed., Alexandri III Romani pontificis Opera omnia. PL 200: 1237-8.
} 
quite unlike those expected and sometimes even found in kingdoms which were under the temporal authority of the pope.

Portugal was not alone in its grant of papal protection, a category which included other kingdoms also and which has been investigated by Johannes Fried. He traced the use of papal protection for lay princes, most obviously in the kingdom of Aragon. ${ }^{56}$ Despite Fried's clear reading of the papal letters to Aragon as showing no evidence of vassalage, but rather in the manner of patronal protection, it is still not uncommon to hear Aragon referred to as a papal fief. Such a conclusion becomes untenable once one appreciates the subtleties of language which the papacy used. By 1088/9 at the latest, Aragon was paying a census to the Holy See ${ }^{57}$ However, the documentation of Sancho Ramirez did not make use of any language which can be described as 'feudal', and there was no reference to anything other than papal protectio and tutela - protection and tutelage. ${ }^{58}$ The kings of Aragon never performed homage and there is little indication that they swore any kind of oath of fidelity before the coronation of 1204. Accordingly Fried argued that they were not feudatories of the papacy, as has been suggested, but under papal protection.

Mattoso also pointed to the similarity between the Portuguese relationship with the papacy, and the alliance between Rome and Aragon and between Rome and the county of Besalú. ${ }^{59}$ Anne Duggan concurred that Aragon, Besalú and Portugal were under papal protectio rather than temporal sovereignty; in these territories there was 'no question of homage or military aid'. ${ }^{60}$ None of these gave military aid, but Afonso had once performed homage to the papal legate. This homage did not constitute an entry into vassalage, however. Fried pointed to numerous other cases of papal protection for lay princes - both permanent,

\footnotetext{
${ }^{56}$ Fried, Der päpstlicher Schutz für Laienfürsten, passim.

${ }^{57}$ Fried, Der päpstlicher Schutz für Laienfürsten, 67.

${ }^{58}$ Fried, Der päpstlicher Schutz für Laienfürsten, 67-81.

${ }^{59}$ Mattoso, D. Afonso Henriques, 214.

${ }^{60}$ A. Duggan, 'Alexander ille meus: the Papacy of Alexander III', in Pope Alexander III (1159-81), eds. Clarke and Duggan, 43-4.
} 
as for Aragon and Portugal, and temporary, as for princes on Crusade. ${ }^{61}$ Portugal fits well within this trend of more permanent protectio and tutela - the terminology was similar, as were the rights and duties which were expected. The papacy would 'protect' the kingdom in return for payment of a census, with no other specific duties outlined. In the cases of temporary papal protection, for princes on Crusade for example, the recipient was unlikely to owe a census. Presumably this was because they were being protected for their willingness to fight for the Holy Land. The common features of longer-term papal protection for lay princes were also common to the papal protection grants to monasteries - census and protectio. There is, however, a possible difference between the Aragonese and the Portuguese protectio.

This protection - Schutz - was after the manner in which monasteries were taken under papal protection, most obviously in Aragon with the royal monastery of Montearagon. ${ }^{62}$ The kind of feudo-vassalic relationship with the papacy that Fried was contrasting with protectio is in fact not easy to find anywhere before the thirteenth century. This can make a distinction difficult to draw. However, his argument that Aragon cannot be interpreted as a 'fief' is convincing; the kingdom was never so described and the privileges and letters for Aragon - like those for Portugal - had numerous similarities to those given to ecclesiastical institutions under papal protection.

In a like manner it seems clear that Portugal's relationship with the Holy See was that of protégé rather than papal vassal. The only homage which the king of Portugal ever did to the papal legate was merely to serve as a confirmation that he would stand by the articles of their agreement, that is, that he would pay a yearly census in return for the protection of Rome. The pope would recognise that no-one should prey on his kingdom and that the soul of the king would be assured of preferential treatment in the life to come. At no point did this relationship resemble any sort of temporal lordship.

\footnotetext{
${ }^{61}$ Fried, Der päpstlicher Schutz für Laienfürsten, 261-4 and passim.

${ }^{62}$ Fried, Der päpstlicher Schutz für Laienfürsten, 79-80.
} 
Like Aragon, Portugal had a royal monastery under papal protection: Santa Cruz de Coimbra. As with Montearagon, the monastery was stated to be 'under the tutelage and defence' of the Holy Roman Church. ${ }^{63}$ The similarities between the wording found in these examples of papal protection for monasteries and for kingdoms certainly suggest that Portugal's relationship with the papacy was in the same mould as ecclesiastic protectio.

The formulae of papal protections for Santa Cruz and for several other monasteries and churches in Portugal were consistent. As in the case of the protection for the kingdom, it was protectio and similar terminology which occurred with the most frequency. ${ }^{64}$ A grant of protection for the bishop of Coimbra from the early 1140s put both the bishop and his church under the protection and tutelage of the papacy and St Peter, but with no payment. ${ }^{65}$ An 1139 grant put the church of Salvador de Grijó under the protection of St Peter and the papacy. In this case an annual payment was requested in return for the permission to conduct services even when the land is under interdict. The payment required was two maravedís every year. ${ }^{66}$ This grant was confirmed, under the same terms, in $1144 .{ }^{67} 1144$ also saw a second grant of protection for the bishop of Coimbra, again placing him under the tutelage and protection of St Peter and the papacy, and again with no mention of any payment. ${ }^{68}$ Both of the grants to the bishop seemed most concerned with preventing other bishops or archbishops from interfering with the bishop of Coimbra's parishioners. The grant to the church on the other hand was a confirmation of the church's possessions and a right to hear the divine office even when under ecclesiastical interdict.

\footnotetext{
${ }^{63}$ Pinto de Azevedo, ed., Documentos medievais Portugueses: documentos régios, vol. 1, 317-18: 'sub tutela et defensione sancte Romane ecclesie'. Also Erdmann, ed., Papsturkunden in Portugal, 219-22, 325-8.

${ }^{64}$ For use of protectio with regards to the papal-royal relationship, see n. 35 above.

${ }^{65}$ Erdmann, ed., Papsturkunden in Portugal, 195: 'sub beati Petri tutelam nostramque protectionem'.

${ }^{66}$ Erdmann, ed., Papsturkunden in Portugal, 190-2: 'sub censu annuo duorum morabitinorum in beati Petri protectione ac nostra'.

${ }^{67}$ Erdmann, ed., Papsturkunden in Portugal, 204-7: 'sub beati Petri et nostra protection ... Ad inditium ... duos morabitinos ... persolvetis.'

${ }^{68}$ Erdmann, ed., Papsturkunden in Portugal, 207-9: 'sub beati Petri tutelam protectionemque nostram'.
} 
There were several more grants of papal protection for monasteries, churches and ecclesiastical chapters from twelfth-century Portugal. These all followed a similar pattern and were themselves similar to the protection granted to the kingdom. All the grants used some variation of the phrasing: sub beati Petri et nostra protectione - 'under our and St Peter's protection' - as the royal-papal letters were most prone to. ${ }^{69}$ There was some minor variation; an 1173 grant of Cardinal Jacintus, the legate, used 'under our protection and of the blessed apostles Peter and Paul and of the Roman Church'. ${ }^{70}$ However, it was the concept of protectio that was the defining element present throughout these grants.

Furthermore in 1211 Innocent took both of Sancho I's daughters and their possessions under papal protection using exactly the same formulation: sub beati Petri et nostra protectione..$^{71}$ This grant was clearly meant to secure the personal property of the two daughters against Sancho's eldest son, the future Afonso II (1211-23), since it was issued shortly after the confirmation of Sancho's will. ${ }^{72}$ The language used here was the same as was used to describe the kingdom's relationship with the papacy and here also the purpose of this document was to protect the lands of the daughters. It too was similar to many of the monastic protection grants.

Not all of these ecclesiastical protection grants mandated the paying of an annual census, as the kingdom had to. There might appear to be a modest correlation between those institutions granted the right to conduct Mass, when the land is under interdict, and those which had to pay a yearly tribute. For example, Salvador de Grijó in 1139, Salvador de Grijó in 1144, São Vicente de Fora in 1191 and Salvador de Grijó again in 1195 all received

\footnotetext{
${ }^{69}$ Erdmann, ed., Papsturkunden in Portugal, 190-2, 195, 204-7, 207-9, 230-2, 234-6, 237-9, 241-2, 291-3, 294-6, 335-8, 342, 345-8, 355, 369-72.

${ }^{70}$ Erdmann, ed., Papsturkunden in Portugal, 241-2: 'sub beatorum apostolorum Petri et Pauli et Romane ecclesie ac nostra protectione'.

${ }^{71}$ Migne, ed., Innocentii III ... Opera omnia, vol. 3. PL 216: 474. See also Linehan, Portugalia pontificia, vol. $1,131-2$ (no. 71).

${ }^{72}$ M. Violante Branco, 'The General Laws of Alfonso II and his Policy of "Centralisation": a Reassessment', in The Propagation of Power in the Medieval West: Selected Proceedings of the International Conference Groningen 20-23 November 1996, eds. M. Gosman, A. Vanderjagt and J. Veenstra (Groningen: Egbert Forsten, 1997), 80-1.
} 
permission to conduct the divine office when the land was under interdict, and all paid an annual sum, two maravedís for Grijó and four for São Vicente. ${ }^{73}$ There was also an 1184 grant to São Vicente, however, which confirmed their right to hold Mass when the land was under interdict but did not mention any payment. ${ }^{74}$ It could be that this was just an oversight of this particular letter, but it is more likely the case that the link between the two was not particularly strong. Certainly of these four grants which contained both elements, there is little indication that they were dependent. The 1144 grant to Grijó explained that the divine office may be performed behind closed doors, if the land was under interdict. It then immediately continued: 'to evidence of which liberty from the Roman Church ... you will pay two maravedís every year'. ${ }^{75}$ The 1139 and 1195 grants to Grijó altered the order of the letter and the payment appears to refer to the protectio as a whole. The 1191 protection for São Vicente added 'that the same church should exist under ours and St Peter's protection'76 to the standard clause regarding the annual payment, making it explicit that the payment was for the entire protective grant, rather than just for a particular right. It does not seem therefore that one can definitely tie the payment of an annual pension with any particular rights given by papal protection. Doubtless some inconsistency was caused by the fact that it was the monasteries and churches themselves which had to request protectio, or a confirmation of their previous protectio. The papacy does not seem to have ensured that they always received the confirmation on the same terms as the original grant. The Curia was dependent on what was presented to it in the petition.

We should now turn back to the census payable from Afonso and his heirs. Other than the general notice of protectio, Portugal was not given any other particular rights in the papal grants. Certainly it was not freed from excommunication by prelates as the kings of Aragon

\footnotetext{
${ }^{73}$ Erdmann, ed., Papsturkunden in Portugal, 190-2, 204-7, 345-8, 369-72.

${ }^{74}$ Erdmann, ed., Papsturkunden in Portugal, 291-3.

${ }^{75}$ Erdmann, ed., Papsturkunden in Portugal, 204-7.

${ }^{76}$ Erdmann, ed., Papsturkunden in Portugal, 345-8: 'quod eadem ecclesia sub beati Petri et nostra protectione consistat'.
} 
were. A grant of 1095 to Peter I of Aragon gave to both him and his wife the right not to be excommunicated by bishops or by archbishops or even by papal legates without a specific mandate. This grant was repeated in a 1213 bull of Innocent III to Peter II. ${ }^{77}$ Similar privileges were given to Raymond Berenger IV of Barcelona and Aragon in 1156-8 and James I of Aragon in 1227, most likely at the request of the Aragonese. ${ }^{78}$ However, even if there was a link between additional rights and the payment the link was neither definite nor consistent. Amongst churches and monasteries under papal protection, some had certain rights of exemption from their bishop as well as the protection which they all possessed..$^{79} \mathrm{In}$ a similar way the kingdoms of Aragon and Portugal were both under papal protection, but Aragon had additional privileges which Portugal did not possess. One could say that Aragon possessed certain features of an exempt, not just protected, monastery. Freedom from sanctions by the local bishop was one such feature of an exempt foundation. ${ }^{80}$ Nonetheless the two kingdoms were both placed within the wider concept of papal protectio. The similarities between the royal protection and the ecclesiastical protection are very clear. The common thread between them is that they were all under the protectio of St Peter and the papacy. The use of papal protectio for lay princes spread more widely in the thirteenth century, as Fried outlined, and covered diverse groups, such as Crusaders and personae miserabiles, as well as ecclesiastical institutions and kingdoms. ${ }^{81}$

Being under papal protectio did not, however, necessitate a wholesale change to the character of papal-Portuguese relations. Colin Morris remarked that:

\footnotetext{
${ }^{77}$ Migne, ed., Innocentii III ... Opera omnia, vol. 3. PL 216: 888-9, 'Nulli episcoporum, nulli archiepiscoporum, nulli sanctae Romanae ecclesiae legato liceat sine certo praecepto nostro adversum te vel tuam coniugem excommunicationis aut interdictis proferre sententiam.'

${ }^{78}$ P. Kehr, ed., Papsturkunden in Spanien I: Katalanien (Berlin: Weidmannsche Buchhandlung, 1926), 365-6 (1156-8); Fried, Der päpstlicher Schutz für Laienfürsten, 330 (1227).

${ }^{79}$ D. Knowles, 'Essays in Monastic History, IV. The Growth of Exemption', Downside Review 50 (1932): 2018.

${ }^{80}$ Knowles, 'Essays in Monastic History, IV', 206.

${ }^{81}$ Fried, Der päpstlicher Schutz für Laienfürsten, 261-4.
} 
Where Innocent [III] was overlord, he was inclined to intervene more actively than usual in support of royal authority or in exhorting the king to perform his duties justly, but (specific and limited rights apart) he did not behave in a fundamentally different way in tributary kingdoms from other countries. ${ }^{82}$

Morris, while not mentioning Portugal specifically, included Aragon in his list of countries which 'traditionally acknowledged the pope as their overlord', ${ }^{83}$ but neither Aragon nor Portugal can be considered as being under anything other than protection. An absence of a clear distinction between protectio and 'overlordship' may have obscured differences between the papacy's actions with regards to each.

To talk of the papacy pro-actively changing its 'policy' may be misleading. Papal government was primarily reactive - it was a rescript government. ${ }^{84}$ Such a system did not lend itself to the pro-active enforcement of consistent policies or attitudes over long periods of time. ${ }^{85}$ To ask whether papal protectio significantly altered papal-Portuguese relations is to risk ignoring the primacy of petitioners to the papacy. The situation in which the papacy found itself, and the appeals it received, dictated its actions. This is not to say that the papacy was incapable of consistency in a particular matter. For 36 years (1143-79) the popes had refused to address Afonso as 'king', although he clearly wished them to do so. But consistently rejecting something is much easier for a rescript government than advancing an unrequested policy; the second is pro-active, whereas the first only requires continued

\footnotetext{
${ }^{82}$ C. Morris, The Papal Monarchy (Oxford: Oxford University Press, 1989), 426.

${ }^{83}$ Morris, Papal Monarchy, 426.

${ }^{84}$ Morris, Papal Monarchy, 212.

${ }^{85}$ While not dealing with rescript government, a general scepticism of 'policy' is implicit in Duggan's argument that Adrian IV's journey from an alliance with the Holy Roman Empire to being forced into making an agreement with the kingdom of Sicily was dictated by the events in which Adrian found himself, not a considered shift from a 'pro-imperial' to a 'pro-Norman' policy, as previously thought. A. Duggan, 'Totius Christianitatis caput. The Pope and the Princes', in Adrian IV The English Pope (1154-1159), eds. A. Duggan, B. Bolton (Aldershot: Ashgate, 2003), 106-38. Thomas Smith has argued for the initiative of lay powers in the Crusade decision-making of Honorius III: 'Honorius III and the Crusade: Responsive Papal Government Versus the Memory of His Predecessors", in The Church on its Past, eds. P. Clarke and C. Methuen. Studies in Church History 49 (Woodbridge: Boydell, for the Ecclesiastical History Society, 2013), 99-109.
} 
denials. ${ }^{86}$ In this way the papacy was able to produce a 'policy', declining to style Afonso 'king'. But it cannot be denied that the impetus for papal protection for Portugal came from Afonso and so, most likely, did the negotiations which granted him the style of king. The removal of Sancho II from the government of Portugal by Innocent IV in 1245 did not arise from specific papal rights, but resulted from decades of clerical-royal antagonism and the efforts of numerous magnates and clergy within Portugal. It was they who enlisted the support of Innocent IV. ${ }^{87}$ The original protectio was granted at the request of the Portuguese and it was Afonso who thought he had most to gain from it. The relationship could have provided a justification for papal intervention in Portugal in some circumstances. It might have made Portuguese ecclesiastics more willing to appeal to Rome for aid (as they did in the years leading up to 1245), but if protectio caused a change in papal-Portuguese relations it could only be by the activity of the Portuguese. It is very doubtful that protectio meant the papacy would intervene of its own accord more often. The impetus still lay with the petitioner. Protectio did not necessitate a wholesale change in the nature of relations, it could grant a king privileges, such as Peter I of Aragon's right not be excommunicated by his bishops, but it did not normally form a basis for papal action. The only evidence we have of any pope writing to Portugal of his own initiative is Innocent III's request for the unpaid census.

There can be little doubt that to use terms like 'fief' or 'vassal' to describe the papalPortuguese relationship is unhelpful. It was instead 'protection', in the manner of an ecclesiastical establishment, which Portugal received, a case of the increasing extension of papal protection to rulers. A relationship where the papacy had very few active "rights"

\footnotetext{
${ }^{86}$ Iben Fonnesberg-Schmidt also notes that 'the Curia was reactive, rather than proactive, but I suggest that it had more leeway, in exercising discretion and refusing to meet the petitions it received', specifically in the context of the Baltic Crusades: The Popes and the Baltic Crusades 1147-1254 (Leiden: Brill, 2007), 21. The papacy clearly had certain aims and intentions, but rarely was pro-active in their enforcement.

${ }^{87}$ E. Peters, The Shadow King: Rex inutilis in Medieval Law and Literature, 751-1327 (New Haven: Yale University Press, 1970), 135-69; for example, 150, for Afonso of Boulogne (brother of Sancho II) as the major complainant in the annulment of Sancho II's marriage.
} 
suited the nature of the Curia, and its rescript form of government, perfectly. To expect to find to find an alliance which encouraged frequent papal intervention, when the papacy's governmental structure was profoundly reactive, is very unlikely. Protectio is exactly the kind of relationship which would be developed by a rescript government, where the papacy only had to be pro-active in one way: collecting the census. Otherwise it was incumbent upon the recipients of protectio to appeal to the pope when necessary, as when Sancho I requested confirmation of his will. Protectio was a quintessentially papal system, unlike 'overlordship', which might imply a far greater degree of active intervention. That was not the way of the twelfth-century papacy. It was Afonso who arranged the alliance and it is unlikely that the papacy often took the initiative in the new relationship without a Portuguese catalyst.

Benedict Wiedemann is a $\mathrm{PhD}$ student at University College London. His thesis title is 'Papal Overlordship and Protectio of the King, c.1000-1373'. He completed his BA at University College London in 2012 and his MA in 2013, starting his PhD there that year. 